\title{
Benign Thoracic Neoplasm
}

National Cancer Institute

\section{Source}

National Cancer Institute. Benign Thoracic Neoplasm. NCI Thesaurus. Code C4565.

A non-metastasizing neoplasm arising from any of the organs of the thoracic cavity.

Representative examples include pleural adenomatoid tumor, chest wall lipoma,

mediastinal schwannoma, and lung hamartoma. 